May 2002

\title{
Distribution Keiretsu, FDI and Import Penetration in Japan
}

\author{
David Flath*
}

\begin{abstract}
An independent wholesaler with many different upstream suppliers is likely to be better at market coverage than if it were the subsidiary of just one supplier. But where wholesale efforts are focused on resolving externalities (by establishing and administering a directed marketing channel), efforts at expanding market coverage have greater marginal cost and will be commensurately retrenched, so independent wholesaling has a smaller payoff. This suggests that directed marketing channels? in Japan known as distribution keiretsu? are more likely than others to be headed by a primary wholesaler that is vertically integrated with the manufacturer. We demonstrate the empirical validity of this by showing that foreign direct investment in Japanese wholesaling is heavily concentrated in marketing channels with relatively high incidence of distribution keiretsu. These same marketing channels tend to have a slightly lower rate of import penetration which is indirect evidence that impediments to inward foreign direct investment still existed in Japan in 1997, our year of observation.
\end{abstract}

*North Carolina State University and Kyoto Institute of Economic Research (Kyoto University). This research was generously supported by a grant from the Abe Fellowship Program of the Social Science Research Council and the American Council of Learned Societies with funds provided by the Japan Foundation Center for Global Partnership. I thank seminar participants at Kansai University, Nanzan University and Hitotsubashi University for their comments on earlier drafts.

David Flath

Kyoto Institute of Economic Research, Kyoto University

Yoshida-Honmachi, Sakyo-ku, Kyoto 606-8501

JAPAN.

Tel. $+81-75-753-7137$

Fax. +81-75-753-7198

E-mail.david_flath@ncsu.edu 


\section{Distribution Keiretsu, FDI and Import Penetration}

\section{Introduction}

Although it is widely conjectured that Japanese marketing channels with vertical restraints (socalled distribution keiretsu) are more difficult for foreigners than for domestic firms to penetrate there have as yet been no empirical studies of this hypothesis. Data both on the incidence of distribution keiretsu and extent of foreign purchases by wholesalers is available from the 1986 survey of wholesalers conducted by MITI, for 80 different 4 digit s.i.c. lines of wholesale business (Unfortunately this is the latest such survey with this sort of data). In the following I will attempt to analyze these data in a revealing way. At the outset we need to reflect for a moment on why distribution keiretsu and import penetration are plausibly linked. They are linked because effective marketing through channels with distribution keiretsu is more likely to require that the primary wholesaler is vertically integrated with the manufacturer, which for foreign suppliers entails their directly investing in Japanese wholesaling. Impediments to inward FDI in Japan thus have a disproportionately adverse affect on import penetration through marketing channels with distribution keiretsu.

Distribution keiretsu is the name for a marketing channel in Japan with vertical restraints. This is not really a Japanese peculiarity per se. What are called ? directed marketing channels? in the academic marketing literature of the US amount to virtually the same thing as distribution keiretsu. These are marketing channels in which the manufacturer, or sometimes a primary wholesaler, attach preconditions or contractual stipulations to the activities of downstream distributors of the product. The stipulations vary but fall under the broad heading ? vertical restraints?. They include stipulations regarding prices (minimum price, maximum price, set price), stipulations of exclusivity, and customer assignments. Antitrust law is preoccupied with the possibility that vertical restraints might be part of a cartel scheme, and in a few instances they have been shown to be that. But economic analysis suggests that in many more instances vertical restraints are there to address externalities in marketing. Where several retailers (wholesalers) with overlapping territories supply the same product, promotional efforts by any one increases demand for the others. In the absence of special measures coordinating their efforts they each underinvest in promotional efforts, both from the point of view of the group and from the standpoint of economic efficiency. The vertical restraints achieve such coordination and lower marketing costs. This is a common feature of many economic models of vertical restraints. See for example Telser (1960) Mathewson and Winter (1984), or Rey and Tirole (1986). Also see Flath (1989) for applications of such models to Japanese cases.

Where administering a system of vertical restraints is an important aspect of marketing, the manufacturer and primary wholesaler are more likely to be vertically integrated. This is because the very externalities that give rise to vertical restraints also lower the cost of vertical integration. The many aspects of wholesale marketing that cannot be identified ex ante or verified ex post are necessarily left to the discretion of an independent wholesaler. The economic incentive to perform these noncontractible tasks then resides in the market-determined sharing of economic rent between the manufacturer and wholesaler. In general this incentive remains imperfect. Vertical integration enables the manufacturer to direct the noncontractible wholesale efforts itself with consequent 
improvement in outcome. But in vertically integrating, the manufacturer necessarily foregoes the comparative advantage of an independent wholesaler at expanding market coverage. An independent wholesaler that stocks many products and has many customers is better able to expand market coverage than if it were the captive subsidiary of just one manufacturer, even if it has less incentive to do so. This is the fundamental tradeoff in integration of manufacturing and wholesaling: ability at market coverage (independence) versus incentive both at market coverage and resolution of externalities (vertical integration). Externalities are likely to tip this calculation in favor of ? incentive?, because efforts to widen market coverage have a lower payoff if externalities are present. This is because widening market coverage increases the externalities and further complicates their resolution by raising the costs of administering a system of vertical restraints. Thus where externalities are present, vertical integration between manufacturer and primary wholesaler is more likely. ${ }^{1}$ Vertical integration of wholesaling with manufacturing and administration of a directed marketing channel are complements in the sense of Milgrom and Roberts (1995).

This study extends and complements several previous ones that have empirically analyzed integration of manufacturing and wholesaling in international sales. Anderson and Coughlan (1987) analyze the choice between independent and integrated foreign distribution channels in 94 overseas operations of 36 U.S. based semiconductor firms. They find that integration is associated with survey responses indicative of asset specificity and product differentiation. Klein, Frazier and Roth (1990) analyze the foreign marketing channel integration decisions of 510 Canadian manufacturing firms in a wide set of different industries. They too found that survey responses indicative of asset specificity were associated with integration. Sakakibara and Serwin (2000) find that Japanese multinational manufacturing firms affiliated with any of the six financial keiretsu were less likely than others to have made direct wholesale investments in the US. They argue that these firms more than others have close and long-term relationships with general trading companies and this obviates their need to sell through US-based independent wholesalers if not themselves integrating into wholesaling? the Japanbased general trading companies act as their wholesalers. All of these studies identify the tradeoff in integration of manufacturing and wholesaling as between the superior control of salesmen that accompanies integration versus the economies of scale and scope that can be achieved in dealing through an independent wholesaler. Roughly speaking, this is the perspective adopted here also, but with a twist. Namely, the wholesale activities that benefit the most from close control of employees? activities pertaining to the administration of a directed marketing channel? actually compete with the ones that benefit from expanded scale and scope? efforts to widen market coverage. In an extreme case, the choice between integration and independence might actually entail a choice of which of the two sorts of competing activities to perform at all. This same kind of tradeoff has been highlighted by Baker and Hubbard (2001) as important in explaining the decision of shippers to use their own fleet of trucks or contract with independent truckers. Independent truckers can not easily

${ }^{1}$ This same logic applies to vertical integration of separate wholesalers. And as demonstrated by Nariu and Flath (1993) marketing channels in Japan with a higher incidence of distribution keiretsu tend to have fewer wholesale steps. 
be made to supply ancillary services such as careful off-loading of shipments, but are well positioned to find matching back-hauls. Companies that use their own private truck fleets to deliver their goods face the opposite conditions. Independence thus makes more sense where special non-contractible driver services have less value and foregoing them altogether might be the lesser of two evils. In the language of Holmstrom (1999) we might best consider ? the firm as a subeconomy which regulates trade according to second-best principles? (p.89).

To make these ideas precise we first develop a stylized example. We then demonstrate the ideas? empirical validity in addressing the issues raised in the opening paragraph, by showing that foreign direct investment in Japanese wholesaling is indeed heavily concentrated in marketing channels with relatively high incidence of distribution keiretsu. These same marketing channels tend to have a slightly lower rate of import penetration, which is indirect evidence that some impediments to inward foreign direct investment still existed in Japan in 1997, our year of observation.

\section{Economic Aspects of Foreign Direct Investment in Wholesaling}

In this section we present a simple example that more precisely represents the economic forces that bear on a manufacturer? s choice to vertically integrate (i.e. directly invest) in wholesaling. We begin with the calculations of a vertically integrated firm with regard to its wholesale activities.

\section{Vertically integrated wholesaler}

Let $\mathrm{s}$ be the extent of the captive wholesalers? activities directed at resolving externalities among downstream distributors, and let e be the extent of the wholesaler?s efforts to widen the market coverage. We suppose that both activities add value but that more of either raises the marginal cost of the other. Let the cost of these activities be $\mathrm{C}=$ ? $(\mathrm{s}+\mathrm{e})^{2}$. Denote by $\mathrm{V}$ the value of these activities and specify:

$$
\text { (1) } \quad \mathrm{V}=\mathrm{ms}+\mathrm{ge}-\mathrm{se}-? \mathrm{~s}^{2}-? \mathrm{e}^{2} \text {, }
$$

where $m>0$ and $g>0$ are parameters determining the marginal product of wholesale activities. For products that require special promotion or service to be marketed effectively, special measures to align the interests of downstream firms are valuable and $\mathrm{m}$ is high. For products such as convenience goods that require wide market coverage to be marketed effectively g is high. The third term reflects our presumption that measures to widen coverage have a higher marginal cost the more extensive are activities aimed at resolving externalities, and vice versa.

The vertically integrated firm chooses positive values of $s$ and e to maximize $V$. There is no interior solution, only a corner solution. The solution values depend upon the parameters as follows:

(2) If $m \_g$, then $\mathrm{s}^{*}=0$ and $\mathrm{e}^{*}=\mathrm{g}$.

If $\mathrm{g} \_\mathrm{m}$, then $\mathrm{e}^{*}=0$ and $\mathrm{s} * \mathrm{~m}$.

This implies that if $\mathrm{m}>\mathrm{g}$ the value of wholesale activity is $\mathrm{V}=? \mathrm{~m}^{2}$, and if $\mathrm{g}>\mathrm{m}$ the value is $\mathrm{V}=? \mathrm{~g}^{2}$. The vertically integrated wholesaler only engages in the activity with the greater marginal product. If 
$\mathrm{m}=\mathrm{g}$ then there are two solutions, both of which are corner solutions.

\section{Independent wholesaler}

Now consider the calculation of an independent primary wholesaler. We introduce some additional presumptions in line with our earlier discussion. First, we presume that an independent wholesaler?s efforts at widening market coverage have a greater marginal product than if the wholesaler were the captive subsidiary of a single manufacturer. Second we presume that the wholesaler?s efforts are not contractible. Finally, bargaining between the manufacturer and independent wholesaler divides the economic rent equally. Let the costs be the same as assumed for a vertically integrated wholesaler. The total value becomes

$$
\mathrm{V}=\mathrm{ms}+? \text { ge }-\mathrm{se}-? \mathrm{~s}^{2}-? \mathrm{e}^{2},
$$

where ? $>1$ reflects the presumed comparative advantage of an independent wholesaler at efforts devoted to widen market coverage. The independent wholesaler chooses effort levels $\mathrm{s}$ and e to maximize its share in this value that results from bargaining. To keep matters simple we presume that neither the wholesaler nor the manufacturer have outside opportunities. The wholesaler? s objective function in choosing the noncontractible levels for s and e becomes:

$$
\mathrm{W}=?(\mathrm{~ms}+? \mathrm{ge})-\mathrm{se}-? \mathrm{~s}^{2}-? \mathrm{e}^{2}
$$

Again there is a corner solution and its value depends on the parameters as follows:

$$
\begin{aligned}
& \text { If } \mathrm{m}_{-} ? \mathrm{~g}, \text { then } \mathrm{s}^{*}=0 \text { and } \mathrm{e}^{*}=? ? \mathrm{~g} \text {. } \\
& \text { If } ? \mathrm{~g}_{-} \mathrm{m} \text {, then } \mathrm{e}^{*}=0 \text { and } \mathrm{s}^{*}=? \mathrm{~m} \text {. }
\end{aligned}
$$

This implies that if $\mathrm{m}>$ ? $\mathrm{g}$ the value of wholesale activities is $3 / 8 \mathrm{~m}^{2}$, and if $? \mathrm{~g}>\mathrm{m}$ the value is $3 / 8 ?^{2} \mathrm{~g}^{2}$. The independent wholesaler only engages in the activity with the greater marginal product. $\mathrm{If} \mathrm{m}=$ ? $\mathrm{g}$, then there are two corner solutions.

The emphasis on asset specificity in the earlier empirical studies of FDI in wholesaling of Anderson and Coughlan (1987) and Klein, Frazier and Roth (1990) is premised on a presumed association between asset specificity and non-contractibility of efforts. For instance if wholesale efforts include special training of employees then any promised reimbursement for the costs of such training are subject to ex-post renegotiation and thus not credible ex-ante. The choice of effort levels by an independent wholesaler are thus sub-optimal as in the present example. Vertical integration resolves this sort of hold-up problem and so is associated with the special in-house training of employees. In this line of thinking vertical integration achieves first-best effort levels but may have, presumably does have, some special disadvantages of its own that are avoided under independence. In the example here the disadvantage of vertical integration resides in the superior ability of an independent wholesaler over a captive subsidiary wholesaler at some of the very efforts subject to hold-up. Comparison of the two regimes, vertical integration and independence, thus amounts to a comparison of second-bests. 


\section{Comparing the two regimes}

Introduce a variable ? to indicate vertical integration or not. ?=1 indicates that the primary wholesaler and manufacturer are vertically integrated. ? $=0$ indicates that the primary wholesaler is independent of the manufacturer. Total value depends on the parameters as follows (To simplify the expression we ignore the cases having two solutions):

$$
\begin{aligned}
& \text { If } \mathrm{m}>\mathrm{g}>\mathrm{g} \text {, then } \\
& {\left[?^{*}=1\right. \text { and }} \\
& \mathrm{V}\left(=? ? \mathrm{~m}^{2}+(1-?) ? \mathrm{~m}^{2}\right)=? ? \mathrm{~m}^{2}+? \mathrm{~m}^{2} \text {. } \\
& \left.\mathrm{V}^{*}=? \mathrm{~m}^{2}\right] \\
& \text { If ? } \mathrm{g}>\mathrm{m}>\mathrm{g} \text {, then } \\
& \mathrm{V}=? ? \mathrm{~m}^{2}+(1-?) ? ?^{2} \mathrm{~g}^{2} \\
& \text { [if } ?^{2} \mathrm{~g}^{2} / \mathrm{m}^{2}<4 / 3 \text {, then } ?^{*}=1 \text { and } \mathrm{V}^{*}=? \mathrm{~m}^{2} \text { ]. } \\
& \text { [if } ?^{2} \mathrm{~g}^{2} / \mathrm{m}^{2}>4 / 3 \text {, then } ?^{*}=0 \text { and } \mathrm{V}^{*}=?^{2} ?^{2} \mathrm{~g}^{2} \text { ]. } \\
& \text { If } ? \mathrm{~g}>\mathrm{g}>\mathrm{m} \text {, then } \\
& \text { [if } ?^{2}<4 / 3 \text {, then } ?^{*}=1 \text { and } \\
& \mathrm{V}=? ? \mathrm{~g}^{2}+(1-?) ? ?^{2} \mathrm{~g}^{2} \\
& \text { [if } ?^{2}>4 / 3 \text {, then } ?^{*}=0 \text { and } \\
& \left.\mathrm{V} *=? \mathrm{~g}^{2}\right] \text {, } \\
& \left.\mathrm{V}^{*}=? ?^{2} \mathrm{~g}^{2}\right] \text {. }
\end{aligned}
$$

The meaning of this is actually straightforward. Under either regime only the activity with the greater marginal product is pursued. But we also presume that efforts to expand market coverage have a greater marginal product if the wholesaler is independent. In switching between regimes there might also be a switch in activities with only efforts to counteract externalities under vertical integration and only efforts to widen coverage under independence (true if ? $g>m>g$ ). This would be decisive in favoring independence if and only if the greater comparative advantage of an independent wholesaler dominated the effect of noncontractibility (which would require that $?^{2}>4 / 3$ ). In the other cases, switching regimes would not switch activities but would only change their extent. Under vertical integration there would be more intense efforts to counteract externalities (if $\mathrm{m}>\mathrm{g} \mathrm{g}>\mathrm{g}$ ) and this would be decisive in favoring vertical integration. Under independence there would be more intense efforts to widen market coverage (if ? $\mathrm{g}>\mathrm{m}$ ), but this would only be decisive in favoring independence if the greater comparative advantage of an independent wholesaler dominated the effect of noncontractibility (which again would require that $?^{2}>4 / 3$ ).

The above can be summarized succinctly in the following.

Result: On the domain $?^{2}>4 / 3, \mathrm{~V}$ is supermodular in $(?, \mathrm{~m},-\mathrm{g},-?)$. On the domain $?^{2}<4 / 3, ?^{*}=1$.

Proof. The second part of the result is evident by inspection of equation(6). Regarding the first part, supermodularity means that the marginal return from increasing a variable (weakly) increases with each other variable. So for example denote by ? V/? $\mathrm{m}$ the marginal return from increasing $\mathrm{m}$. It depends on the other parameters as follows on the domain $?^{2}>4 / 3$ :

If $\mathrm{m}>$ ? $\mathrm{g}>\mathrm{g}$, then ? $\mathrm{V} / ? \mathrm{~m}=(? ?+? \mathrm{~m}$.

If ? $\mathrm{g}>\mathrm{m}>\mathrm{g}$, then ? $\mathrm{V} / ? \mathrm{~m}=$ ? $\mathrm{m}$.

If ? $\mathrm{g}>\mathrm{g}>\mathrm{m}$, then ? $\mathrm{V} / ? \mathrm{~m}=0$.

--So as $\mathrm{g}$ falls (-g increases), ? V/? $\mathrm{m}$ either does not change or else increases from ? $\mathrm{V} / \mathrm{m}=0$ to 
? $\mathrm{V} / ? \mathrm{~m}=\mathrm{m}$ or from $? \mathrm{~V} / ? \mathrm{~m}=0$ to $? \mathrm{~V} / ? \mathrm{~m}=? \mathrm{~m}$.

--And as ? falls (-? increases), ? $\mathrm{V} /$ ? $\mathrm{m}$ either does not change or else increases from ? $\mathrm{V} /$ ? $\mathrm{m}=0$ to ? $\mathrm{V} / ? \mathrm{~m}=\mathrm{m}$ or from $? \mathrm{~V} / ? \mathrm{~m}=0$ to $? \mathrm{~V} / ? \mathrm{~m}=$ ? $\mathrm{m}$.

--And as ? increases, ? $\mathrm{V} /$ ? $\mathrm{m}$ either does not change or else increases from ? $\mathrm{V} / ? \mathrm{~m}=0$ to $? \mathrm{~V} /$ ? $\mathrm{m}=\mathrm{m}$ or from ? $\mathrm{V} / ? \mathrm{~m}=? \mathrm{~m}$ to $? \mathrm{~V} / ? \mathrm{~m}=\mathrm{m}$. The rest of the proof proceeds in the same vein. $\mathrm{Z}$

From the stated result it follows that ?* is monotone non-decreasing in $(\mathrm{m},-\mathrm{g},-?)$. The logic here is due to a theorem (6.1) by Topkis (1978) regarding some implications of supermodularity. That ?* is monotone non-decreasing in ( $\mathrm{m},-\mathrm{g},-\mathrm{-})$ can also be confirmed by inspection of (6). Vertical integration is more likely, the greater is the marginal product of activities directed at counteracting externalities relative to the marginal product of activities directed at widening market coverage. The upshot here is that in Japan, marketing channels with a high incidence of distribution keiretsu ought also to have a high concentration of foreign owned wholesalers.

\section{Empirical Analysis}

Vertical integration between a foreign manufacturer and domestic wholesaler is an instance of foreign direct investment. Japan? s stock of inward foreign direct investment is low in comparison to its outward stocks and in comparison to the inward stocks of the US and the EU. One reason is the generally inhibiting policy of the Japanese government with respect to inward FDI, significantly relaxed only about $1980 .^{2}$ There are probably other reasons too. My point here though is just that any inhibition of inward FDI in Japan would have increased the costs to foreign manufacturers of administering directed marketing channels in Japan. To put it another way, marketing channels in Japan with a high incidence of distribution keiretsu should have been both more likely to host foreign owned wholesale subsidiaries, and to the extent that FDI is impeded, less likely also to be penetrated by imports. In the following we confront these hypotheses with data. We find ample evidence for the first conjecture. Foreign owned wholesale subsidiaries in 1997 were heavily concentrated in Japanese marketing channels with distribution keiretsu. We also find support for the other point, albeit less conclusive. Import penetration itself is slightly less in marketing channels with a high incidence of distribution keiretsu. Perhaps this indicates that economic impediments to inward foreign direct investment in Japanese wholesaling were still present in 1997 even though de jure restrictions had been largely eliminated.

Data and descriptive statistics

a. Foreign Direct Investment

${ }^{2}$ On Japanese government restrictions on inward FDI refer to Flath (2000), p. 170, p. 172 and pp. 196-7. 
Our data on the Japan-based wholesale subsidiaries of foreign firms in 1997, are drawn from Touyou Keizai, Gaishi keikigyou souran (Survey of foreign affiliated companies in Japan), annual (since 1986). This source lists basic data on virtually all the large, foreign-owned enterprises operating in Japan. This listing includes all respondents with book value of equity exceeding 50 million yen and with greater than 49 percent foreign ownership. ${ }^{3}$ About one third of these 1,372 large foreign subsidiaries operating in Japan in 1997 were primarily engaged in wholesaling, 468 firms in all. ${ }^{4}$ Clearly, wholesale affiliates of foreign firms comprise a significant portion of the stock of foreign direct investment in Japan. Fukao and Ito (2001) make this same observation. In fact, wholesaling is a sizeable focus of foreign direct investment generally, not only in Japan. A recent study by Hanson, Mataloni and Slaughter (2001) draws attention to the fact that $20 \%$ of the total worldwide sales of foreign affiliates of US multinationals were the sales of their foreign wholesale affiliates (at p. 25).

Touyou Keizai classifies the foreign affiliates by industry, including eleven subcategories within wholesale trade, and also lists the important products of each individual company. From this information I have further classified the individual companies according to wholesale product lines corresponding to the 4 digit s.i.c. of the Census of Commerce of Japan, our source for other data. I then aggregated the individual company employment within these 4 digit codes to produce EMP97. The variable EMPRAT97 scales these employment figures as percentages of the total employment in each wholesale line of business TOTEMP97 reported in the 1997 Census of Commerce of Japan, Report by Distribution Channel (Wholesaling), Table 2.

It was apparent from mere inspection of the data that the foreign affiliates in Japan?s wholesale industries are heavily concentrated in a few lines of business including machinery, medical instruments, precision instruments, automobiles, automobile parts, electric appliances and toiletries. All of these are products for which marketing has often entailed vertical restraints of one sort or another: manufacturer or wholesaler imposed customer assignments, price restrictions, and the like.

\section{b. Import Penetration}

${ }^{3}$ It also includes those with greater than 20 percent foreign ownership if very large or important but only 10 of the 468 firms classified as wholesalers had less than 49 percent foreign ownership. The modal firm among the 468 had 100 percent foreign ownership.

${ }^{4}$ Besides the large firms, Touyou Keizai, Gaishi keikigyou soran also includes a separate listing (and selected data) for all foreign affiliates of whatever capitalization with more than 20 percent foreign ownership. We do not include these smaller, less tightly controlled enterprises in our investigation. 
Data on Japanese imports by wholesalers and on the scale of wholesale marketing channels is taken from the same source as the total employment figures (same table even): 1997 Census of Commerce of Japan, Report by Distribution Channel (Wholesaling), Table 2. We collect the purchases from foreign sources by wholesalers operating in Japan FORPUR97, the annual sales by wholesalers, and their sales to other wholesalers. Foreign purchases divided by the difference between total sales and sales to other wholesalers is an approximate measure of foreign penetration of each wholesale distribution channel IMPRAT97. This is not quite the same as import penetration per se. Some imports are sales from foreign suppliers directly to final demanders in Japan; they don?t go through wholesale channels and thus they escape the purview of the Census of Commerce. But it turns out that most imports into Japan do go through wholesale establishments. For the 1997 Census of Commerce period of observation (July 1, 1996 to June 30, 1997) value of imports into Japan reported by the Japan Tariff Association ${ }^{5}$ totaled 40 trillion yen compared to the 35 trillion yen total foreign purchases by Japanese wholesalers. In other words, almost 90 percent of Japanese imports do arise as foreign purchases by wholesale establishments (including intracompany foreign shipments).

The wholesale establishments that are the objects of query in the Census of Commerce are classified by the 4 digit s.i.c. wholesale businesses in which they are principally engaged, with ones widely engaged in multiple lines of business classified as general trading companies. The general trading companies? 19 trillion yen in foreign purchases comprised a little more than half of the total foreign purchases by all Japanese wholesalers in 1997. Low foreign penetration of a wholesale marketing channel may well only mean that general trading companies, and not the more specialized wholesalers, are the dominant importers. ${ }^{6}$ And even the more specialized wholesalers are not perfectly specialized. Foreign purchases by some wholesalers actually exceed the total imports of the commodities which they principally trade. With these caveats in mind we nevertheless press ahead.

\section{c. Marketing Channel Characteristics}

For core data on marketing channel characteristics we turn to the Medium and smaller enterprise agency, Basic Survey of Commercial Activity and Structure, for the Wholesale Industry of Japan (hereafter? Basic Survey?). In 1979 and 1986 basic surveys included questions about respondents? arrangements with other firms. ${ }^{7}$ The 1979 and 1986 Basic Surveys (respectively, $4^{\text {th }}$ and $5^{\text {th }}$ surveys) report wholesalers? survey responses regarding their participation in a contractual agreement (distribution keiretsu). In the detailed instructions that accompanied the survey such an agreement is defined as one having any of the following stipulations: special dealing or preferential treatment in the

${ }^{5}$ Nihon kanzei kyoukai (Japan Tariff Association), gaikoku boueki gaikyou (Summary report on trade of Japan), Tokyo: The Association, (monthly).

${ }^{6}$ Unfortunately the data presented in the Census of Commerce do not enable one to discern how the imports of general trading companies are distributed across commodities. There does exist a detailed breakdown of their sales of each type of commodity.

${ }^{7}$ The 1992 survey results are reported at a more aggregated level, not useful for our purpose. The 1998 survey does not include the distribution keiretsu queries. 
sale of wares, capital assistance (i.e. equity participation), or management assistance including dispatch of employees. The survey responses indicate whether the wholesaler is the initiator of such a (distribution keiretsu) agreement (and if so whether it pertains to the manufacturer, other wholesalers, or retailers), and whether it itself is subject to such an agreement (and if so whether this is at the initiative of a manufacturer or of other wholesalers). The survey responses also ask respectively whether the wholesaler has proffered specific types of assistance to its suppliers or to its customers.

I have formed several variables from these data: fraction of wholesalers initiating a distribution keiretsu KSUR and fractions respectively initiating a distribution keiretsu involving other wholesalers KSURW and retailers KSURR. Fraction of wholesalers entered into a distribution keiretsu inititiated by another firm KHAI, and the fractions respectively entered into a distribution keiretsu initiated by a manufacturer KHAIM and by another wholesaler KHAIW.

The means and standard deviations of the data items just described are listed in Table 1 and correlation matrices for some of them can be found in Table 2. From the correlation matrix (Table 2) we can see that the correlation between KHAI and KHAIM is 0.98 . The correlation between KSUR and KSURR is 0.93 . The correlation between KHAI and KSUR is 0.86 and the correlation between KHAIM and KSUR is 0.79. The typical pattern seems to be one in which a manufacturer imposes vertical restraints upon a wholesaler, who in turn itself imposes vertical restraints on retailers. Also notice the positive correlations between foreign affiliate share of total wholesale employment EMPRAT97 and the fraction of wholesalers entered into a distribution keiretsu initiated by a manufacturer KHAIM: 0.45; and between EMPRAT97 and the fraction of wholesalers initiating a distribution keiretsu involving retailers KSUR: 0.45. The foreign wholesale affiliates in 1997 were in this sense concentrated in marketing channels that in 1986 had a high incidence of distribution keiretsu.

Other relevant marketing channel characteristics include ones that fundamentally influence the marginal product of wholesale efforts at resolving externalities or at widening market coverage. Among these characteristics are the wholesale profit margin and the number of wholesale steps. Also, whether the good is a consumer product or an industrial one, and if the former, the number of retail outlets. The analysis of Nariu (1989) is helpful here. Nariu explains how demanders? information gathering behavior shapes the structure of marketing channels. On one extreme are ? experience? goods that demanders purchase sequentially before finally settling on a permanent source of supply. At the other extreme are the ? search? goods that demanders inform themselves about prior to purchase. The choice between these two ways of gathering information is itself an economic one. Nondurable, standardized, small-ticket items tend to elicit ? experience?, while durable, expensive items, with varying complex features elicit the ? search? strategy. Effective marketing of experience goods requires maximum market coverage as demanders are likely to sample from the outlets closest to them. Effective marketing of search goods requires promotion, advertising, and attention to the idiosyncratic variation in local demand all along the distribution channel. For experience goods the market widening activities of wholesalers have a great marginal product. For search goods efforts at resolving externalities along the distribution channel have a high marginal product. The experience goods tend to be standardized items with low wholesale profit margins, many final outlets, and multiple wholesale steps. Industrial marketing channels generally do not have retail outlets and to that extent entail fewer externalities than do marketing channels for consumer products. In line with this discussion I have collected several pertinent variables from the Census of Commerce and the 
Basic Survey:

from the 1986 Basic Survey:

NETPROFR $=$ the average wholesale profit to sales ratio;

and from the 1997 Census of Commerce:

WW97 the fraction of total wholesale sales that were to other wholesalers? a proxy for the number of wholesale steps,

CONSUMER = a dummy variable equal to one if the product line is a consumer item and zero otherwise, and

CONXSTOR $=$ the number of retailers in Japan specializing in sale of such items if they are consumer products and equal to zero otherwise.

Again, the means and standard deviations of all these and the other variables are in Table 1. We now turn to the statistical analysis of these data.

Results

Our research focus is the interdependence between employment in foreign affiliate wholesalers, marketing channel characteristics including incidence of distribution keiretsu, and foreign penetration of wholesale distribution channels. We hypothesize that marketing channels with vertical restraints (distribution keiretsu) are more likely to elicit the establishment of foreign wholesale affiliates. If there are no impediments to FDI then the marketing channels with distribution keiretsu should be no less penetrated than others even in spite of their implied higher incidence of FDI. To the extent that FDI is inhibited, marketing channels with distribution keiretsu are less likely to be penetrated by imports. Additionally, to the extent that FDI is inhibited, such FDI as does exist ought to induce greater import penetration. To fully explore these possibilities requires a two equation system such as Yamawaki (1991) used to analyse Japanese direct investments in U.S. wholesaling. In this kind of specification foreign import penetration both induces the establishment of foreign wholesale affiliates and is itself enhanced by it.

Simultaneity bias is of concern so we begin the analysis with estimates of reduced form equations. The Table 3 includes estimates of two sets of reduced form equations. The dependent variables are respectively EMPRAT97 and IMPRAT97. These are the employment share of the large Japan-based wholesale subsidiaries of foreign firms and the foreign purchases of Japan-based wholesalers as a fraction of their total sales not to other wholesalers. To address the problem of limited dependent variable I also estimated the EMPRAT97 equations using Tobit analysis, easily accomplished with the SHAZAM software. The resulting regression coefficient estimates and t-statistics are very close to the OLS values. These reduced form estimates show that marketing channels with distribution keiretsu (high values for KHAIM) tend to have both higher foreign affiliate employment shares and less import penetration. Wholesale marketing channels for consumer products tend to have more foreign wholesale affiliate employment, and those that have more retail outlets tend to have less import penetration. None of the other variables even approach statistical significance. The structural 
equations are more revealing.

The Table 4 depicts my estimates of the structural equations explaining import shares and FDI (foreign affiliate employment shares). For the import share IMPRAT97 equation this entails a 2SLS estimation procedure. This was not possible for the foreign direct investment EMPRAT97 equation because of the lack of identifying instruments. So instead of an instrumental variable procedure I substituted an earlier observation for import share IMPRAT82 as a right hand side variable in the equation explaining EMPRAT97. I estimated this equation using both OLS and Tobit. The results of these differ little and are highly satisfactory. All of the variables are of the expected sign and statistically significant and together they explain most of the variation in the foreign wholesale affiliate employment share. The import rate equation also has the predicted signs but a much worse fit. As conjectured, import penetration both elicits wholesale foreign direct investment and is itself possibly encouraged by it. Furthermore, in marketing channels where manufacturers form more of the wholesalers into distribution keiretsu (KHAIM is greater) the employment share of foreign wholesale affiliates is greater. Import penetration seems to be less in these same marketing channels which might indicate continuing inhibitions on FDI. Channels for CONSUMER products also elicit more foreign direct investment and induce slightly less import penetration. Consumer products with more retail stores CONXSTOR also elicit more wholesale foreign direct investment. Beyond this, wholesale product lines with higher average profit to sales ratios NETPROFR and fewer wholesale steps WW97 also tend to elicit more wholesale foreign direct investment. All of this comports with our expectation. In short, the equations expose the important empirical determinates of the pattern of foreign direct investment across Japanese wholesale industries. They also provide qualified support for the findings of Yamawaki (1991) that wholesale foreign direct investment not only follows import penetration but also promotes it.

\section{Conclusion}

This paper has made a modest contribution to the theory of vertical integration and has attempted to expose the empirical relationship between foreign direct investment in Japanese wholesaling, distribution keiretsu and import penetration. The theoretical innovation is to identify marketwidening efforts and resolution of externalities (through administration of a distribution keiretsu) as fundamentally competing activities. They may both have value, but the better performance of the one task raises the costs of the other. To integrate manufacturing and wholesaling can entail the decision to forego market widening efforts altogether to more perfectly resolve externalities. Dealing through an independent wholesaler might entail the opposite. In either case the firm achieves a second-best only. These ideas have application to the pattern of foreign direct investment in Japanese wholesaling, for such investment is indeed an example of vertical integration of manufacturing and wholesaling. In full accord with the logic just related, we have found that marketing channels in Japan with a higher incidence of distribution keiretsu are more likely than others to host wholesalers that are subsidiaries of foreign manufacturing companies.

We have also found evidence that inhibitions on inward FDI still existed in Japan in 1997. Japan, compared to the other developed nations, has long had a vanishingly small stock of inward foreign direct investment. There are many possible explanations. Before 1980, government regulations in 
Japan were quite inhibiting, as well-documented by Mason (1992). Since then the flow of FDI into Japan has expanded, but the stock still remains small compared to what is observed in the US or the EU. Perhaps this reflects indigenous factors other than government regulation that make it difficult for foreigners to live and work in Japan or to set up businesses there. These factors include the employment practices of the large Japanese firms that make it difficult to hire executives in mid-career (as suggested by Weinstein (1996)), and also include the myriad difficulties foreigners encounter in mastering the Japanese language and culture. As already mentioned, we have found that foreign penetration of Japanese product markets that elicit distribution keiretsu is likely to be accompanied by direct investment. We have also found that import penetration itself is less likely in these same markets, which indicates that inherent obstacles to foreign direct investment do exist. 


\section{References}

Anderson, Erin and Anne T. Coughlan (1987). ? International Market Entry and Expansion via Independent or Integrated Channels of Distribution?, Journal of Marketing, vol. 51 (January), pp. 71-82.

Baker, George P. and Thomas N. Hubbard (2000). ? Make Versus Buy in Trucking: Asset Ownership, Job Design and Information?, mimeo.

Chụ shou kigyou chou, tsushou sangyou daijin kanbou chousa toukei bu (Small and Medium Enterprise Agency, Ministry of International Trade and Industry, Minister?s Secretariat, Research and Statistics Department), Dai go kai shougyou jittai kihon chousa houkoku sho, Oroshiuri gyou hen (Report on $5^{\text {th }}$ basic survey of commercial activity and structure, as of October 1, 1986, report of wholesale trade), Tokyo: Tsusan toukei kyoukai, February 1989. Table 4, pp.52-9. Table 54, pp.630-637.

Flath, David (2000). The Japanese Economy, Oxford U press.

Flath, David (1989). "Vertical Restraints in Japan," Japan and the World Economy, 1: 187-203.

Fukao, Kyoji and Keiko Ito (2001). Foreign Direct Investment and Service Trade: The Case of Japan?, Taktoshi Ito and Anne O. Krueger, eds., Services Trade in the Asia-Pacific Region, East Asia Seminar on Economics Volume 11, The University of Chicago Press, forthcoming.

Hanson, Gordon H., Raymond J. Mataloni, and Matthew J. Slaughter (2001). ? Expansion Strategies of U.S. Multinational Firms?, NBER working paper 8433.

Holmstrom, Bengt (1999). ? The Firm as a Subeconomy?, Journal of Law, Economics and Organization, vol. 15, no. 1, pp. 74-102.

Mason, Mark (1992). American Multinationals in Japan: The Political Economy of Japanese Capital Market Controls 1899-1980, Harvard University Press.

Mathewson, G.F. and Ralph Winter (1984). ? An Economic Theory of Vertical Restraints?, Rand Journal of Economics, vol. 15, pp. 27-38.

Milgrom, Paul and John Roberts (1995). ? Complementarities and Fit: Strategy, Structure, and Organizational Change in Manufacturing?, Journal of Accounting and Economics, vol. 19, pp. 179-208.

Nariu, Tatushiko (1989). ? Consumers? Information Gathering Behavior and the Struture of Distribution Channels?, ch. 2 in ? Economic Analysis of Marketing and Distribution?, pp. 2243, Economics Ph.D. thesis, North Carolina State University. 
Nariu, Tatushiko and David Flath (1993). "The Complexity of Wholesale Distribution Channels in Japan," in Michael R. Czinkota and Masaaki Kotabe, eds., The Japanese Distribution System, pp. 83-98, Chicago: Probus Publishing Company.

Nihon kanzei kyoukai (Japan Tariff Association), gaikoku boueki gaikyou (Summary report on trade of Japan), Tokyo: The Association, (monthly).

Rey, Patrick and Jean Tirole (1986). ? Vertical Restraints from a Principal-Agent Viewpoint,? in L. Pelligrini and S. Reddy, eds., Marketing Channels: Relationships and Performance, Lexington Books.

Sakakibara, Mariko and Kenneth Serwin (2000). ? U.S. Distribution Entry Strategy of Japanese Manufacturing Firms: The Role of Keiretsu?, Journal of the Japanese and International Economies, vol. 14, no. 1 (March), pp.43-72.

Telser, Lester (1960). ? Why Should Manufacturers Want Fair Trade?? Journal of Law and Economics, vol. 3, pp. 86-105.

Topkis , Donald (1978) ? Minimizing a Submodular Function on a Lattice?, Operations Research, vol. 26, pp. 305-321.

Touyou keizai, Gaishi keikigyou souran ?98 (Survey of foreign affiliated companies in Japan, 1998), Tokyo: Touyou keizai shinpousha, April 1998. ....annual since 1986.

Tsushou sangyou daijin kanbou chousa toukei bu (Ministry of International Trade and Industry, Minister? s Secretariat, Research and Statistics Department), Heisei kyunen shou gyou toukei hyou, dai issatsu sangyou hen (soukatsu hyou) (1997 Census of commerce, volume 1, report by industries (summary)), Tokyo: Tsushou sangyou chousa kai, November 1998, Table 10, pp.298-301.

Tsushou sangyou daijin kanbou chousa toukei bu (Ministry of International Trade and Industry, Minister? s Secretariat, Research and Statistics Department), Heisei kyunen shou gyou toukei hyou, ryutsu keirou betsu toukei hen (oroshiuri hyou) (1997 Census of commerce, report by distribution channel (wholesale)), Tokyo: Tsushou sangyou chousa kai, March 1999, Table 2, pp. 6-201.

Tsushou sangyou daijin kanbou chousa toukei bu (Ministry of International Trade and Industry, Minister?s Secretariat, Research and Statistics Department), Shouwa 57 nen shou gyou toukei hyou, ryutsu keirou betsu toukei hen (oroshiuri hyou) (1982 Census of commerce, report by distribution channel (wholesale)), Tokyo: Tsushou sangyou chousa kai, March 1984, Table 2, pp.162-477. 
Weinstein, David (1996). ? Structural Impediments to Investment in Japan: What have we learned over the last 450 years?? in Masaru Yoshitomi and Edward M. Graham (eds.), Foreign Direct Investment in Japan, Edward Elgar, pp. 136-172.

Yamawaki, Hideki (1991). ? Exports, and Foreign Distributional Activities: Evidence on Japanese Firms in the Untied States?, Review of Economics and Statistics, vol. 73, no. 2 (May), pp. 294-300. 
Table 1. Data on Wholesale Marketing Channels of Japan

\begin{tabular}{|c|c|c|c|}
\hline Name & Description & Sources* & $\begin{array}{l}\text { Average across } 4 \\
\text { digit sic wholesale } \\
\text { marketing } \\
\text { channels in Japan } \\
\text { (s.d.) }\end{array}$ \\
\hline EMPRAT97 & =EMP97/TOTEMP97 & & $\begin{array}{r}0.011 \\
(0.019)\end{array}$ \\
\hline IMPRAT97 & =FORPUR97/(SALES97(1-WW97)) & & $\begin{array}{r}0.093 \\
(0.097)\end{array}$ \\
\hline IMPRAT82 & $=$ FORPUR82/(SALES82(1-WW82)) & $\begin{array}{l}1982 \text { Census of } \\
\text { Commerce }\end{array}$ & $\begin{array}{r}0.055 \\
(0.065)\end{array}$ \\
\hline EMP97 & $\begin{array}{l}\text { Employment in large wholesale subsidiaries of } \\
\text { foreign firms in Japan. (? Large?= with capital } \\
\text { greater than } 50 \text { million yen. } \\
\text { ? Wholesale? = primarily engaged in wholesaling. } \\
\text { ? Subsidiaries of foreign firms? = having greater } \\
\text { than } 49 \text { pct foreign ownership). End of } 1997 . \\
\text { (units=persons) }\end{array}$ & Touyou Keizai & $\begin{array}{r}696 \\
(1,841)\end{array}$ \\
\hline TOTEMP97 & $\begin{array}{l}\text { Employment in all wholesale enterprises in Japan; } \\
\text { June } 1997 . \\
\text { (units=persons) }\end{array}$ & $\begin{array}{l}1997 \text { Census of } \\
\text { Commerce }\end{array}$ & $\begin{array}{r}49,132 \\
(59,224)\end{array}$ \\
\hline FORPUR97 & $\begin{array}{l}\text { Purchases from abroad by all wholesalers in Japan, } \\
\text { July 1, 1996-June 30,1997. (units=millions of } \\
\text { yen) }\end{array}$ & $\begin{array}{l}1997 \text { Census of } \\
\text { Commerce }\end{array}$ & $\begin{array}{r}427,670 \\
(2,078,500)\end{array}$ \\
\hline SALES97 & $\begin{array}{l}\text { Sales of all wholesalers in Japan, July 1, 1996- } \\
\text { June } 30,1997 \text {. } \\
\text { (units=millions of yen) }\end{array}$ & $\begin{array}{l}1997 \text { Census of } \\
\text { Commerce }\end{array}$ & $\begin{array}{r}5,978,300 \\
(9,638,700)\end{array}$ \\
\hline WW97 & $\begin{array}{l}\text { Fraction of sales of wholesalers in Japan that are } \\
\text { to other wholesalers, July 1, 1996-June 30,1997. }\end{array}$ & $\begin{array}{l}1997 \text { Census of } \\
\text { Commerce }\end{array}$ & $\begin{array}{r}0.359 \\
(0.095)\end{array}$ \\
\hline CONXSTOR & $\begin{array}{l}\text { Number of retail stores specializing in same } \\
\text { product line as } 4 \text { digit sic wholesale industry }(=0 \\
\text { for non-consumer products) }\end{array}$ & $\begin{array}{l}1997 \text { Census of } \\
\text { Commerce (vol. 1) }\end{array}$ & $\begin{array}{r}19,074 \\
(31,782)\end{array}$ \\
\hline NETPROFR & $\begin{array}{l}\text { Net profit divided by sales, average for all } \\
\text { wholesalers, Oct. } 1,1985 \text { ? Sept. } 30,1986\end{array}$ & Basic Survey (table 4) & $\begin{array}{r}0.041 \\
(0.013)\end{array}$ \\
\hline KHAI & $\begin{array}{l}\text { Fraction of wholesalers having entered } \\
\text { distribution keiretsu initiated by others }\end{array}$ & $\begin{array}{l}\text { Basic Survey (table } \\
54)\end{array}$ & $\begin{array}{r}0.221 \\
(0.112)\end{array}$ \\
\hline KHAIM & $\begin{array}{l}\text { Fraction of wholesalers having entered } \\
\text { distribution keiretsu initiated by product makers }\end{array}$ & $\begin{array}{l}\text { Basic Survey (table } \\
54)\end{array}$ & $\begin{array}{r}0.162 \\
(0.109)\end{array}$ \\
\hline KHAIW & $\begin{array}{l}\text { Fraction of wholesalers having entered } \\
\text { distribution keiretsu initiated by other wholesalers }\end{array}$ & $\begin{array}{l}\text { Basic Survey (table } \\
54)\end{array}$ & $\begin{array}{r}0.074 \\
(0.026)\end{array}$ \\
\hline KSUR & Fraction of wholesalers themselves having & Basic Survey (table & 0.103 \\
\hline
\end{tabular}




\begin{tabular}{|l|l|l|r|}
\hline & initiated distribution keiretsu & $54)$ & $(0.046)$ \\
\hline KSURW & $\begin{array}{l}\text { Fraction of wholesalers having initiated } \\
\text { distribution keiretsu in their dealings with other } \\
\text { wholesalers }\end{array}$ & $\begin{array}{l}\text { Basic Survey (table } \\
54)\end{array}$ & 0.039 \\
$(0.011)$ \\
\hline KSURR & $\begin{array}{l}\text { Fraction of wholesalers having initiated } \\
\text { distribution keiretsu in their dealings with retailers }\end{array}$ & $\begin{array}{l}\text { Basic Survey (table } \\
54)\end{array}$ & $\begin{array}{r}0.040 \\
(0.034)\end{array}$ \\
\hline
\end{tabular}

* Touyou Keizai=Touyou keizai, Gaishi keikigyou souran ?98 (Foreign affiliated companies in Japan, a comprehensive directory, 1998), Tokyo: Touyou keizai shinpousha, April 1998.

1997 Census of Commerce $=$ Tsushou sangyou daijin kanbou chousa toukei bu (Ministry of International Trade and Industry, Minister?s Secretariat, Research and Statistics Department), Heisei kyu nen shougyou toukei hyou, ryuts $\underline{u}$ keirou betsu toukei hen (oroshiuri hyou) (1997 Census of commerce, report by distribution channel (wholesale)), Tokyo: Tsushou sangyou chousa kai, March 1999, Table 2, pp. 6-201.

1982 Census of Commerce $=$ Tsushou sangyou daijin kanbou chousa toukei bu (Ministry of International Trade and Industry, Minister?s Secretariat, Research and Statistics Department), Shouwa 57 nen shou gyou toukei hyou, ryutsu keirou betsu toukei hen (oroshiuri hyou) (1982 Census of commerce, report by distribution channel (wholesale)), Tokyo: Tsushou sangyou chousa kai, March 1984, Table 2, pp.162-477.

1997 Census of Commerce (vol. 1) = Tsushou sangyou daijin kanbou chousa toukei bu (Ministry of International Trade and Industry, Minister? s Secretariat, Research and Statistics Department), Heisei kyu nen shougyou toukei hyou, dai issatsu sangyou hen (soukatsu hyou) (1997 Census of commerce, volume 1, report by industries (summary)), Tokyo: Tsushou sangyou chousa kai, November 1998, Table 10, pp.298-301.

Basic Survey Chousa (table 4; table 54) = Chu shou kigyou chou, tsushou sangyou daijin kanbou chousa toukei bu (Small and Medium Enterprise Agency, Ministry of International Trade and Industry, Minister? s Secretariat, Research and Statistics Department), Dai go kai shougyou jittai kihon chousa houkoku sho, Oroshiuri gyou hen (Report on $5^{\text {th }}$ basic survey of commercial activity and structure, As of October 1, 1986, Report of wholesale trade), Tokyo: Tsussan toukei kyoukai, February 1989. Table 4, pp.52-9. Table 54, pp.630-637. 
Table 2. CORRELATION MATRICES OF SELECTED VARIABLES

80 observations:

$\begin{array}{lrrrrrrr}\text { IMPRAT97 } & 0.03 & & & & & & \\ \text { KHAI } & 0.43 & -0.22 & & & & & \\ \text { KHAIM } & 0.45 & -0.19 & 0.98 & & & & \\ \text { KHAIW } & 0.06 & -0.17 & 0.40 & 0.21 & & & \\ \text { KSUR } & 0.45 & -0.16 & 0.86 & 0.79 & 0.60 & & \\ \text { KSURW } & 0.40 & -0.24 & 0.68 & 0.60 & 0.56 & 0.74 & \\ \text { KSURR } & 0.32 & -0.16 & 0.72 & 0.61 & 0.67 & 0.93 & 0.54 \\ & \text { EMPRAT97 } & \text { IMPRAT97 } & \text { KHAI } & \text { KHAIM } & \text { KHAIW } & \text { KSUR } & \text { KSURW }\end{array}$

57 observations:

\begin{tabular}{|c|c|c|c|c|c|c|c|}
\hline IMPRAT82 & 0.38 & & & & & & \\
\hline EMPRAT97 & -0.07 & 0.01 & & & & & \\
\hline KHAIM & -0.21 & -0.18 & 0.65 & & & & \\
\hline CONSUMER & -0.21 & -0.38 & 0.27 & -0.03 & & & \\
\hline CONXSTOR & -0.32 & -0.24 & 0.17 & 0.18 & 0.52 & & \\
\hline NETPROFR & 0.00 & -0.04 & -0.03 & -0.10 & -0.36 & -0.02 & \\
\hline WW97 & -0.01 & 0.26 & -0.44 & -0.48 & -0.16 & -0.19 & -0.01 \\
\hline & IMPRAT97 & IMPRAT82 & EMPRAT97 & KHAIM & CONSUMER & CONXSTOR & NETPROFR \\
\hline
\end{tabular}


Table 3. Regression Estimates; Reduced Forms

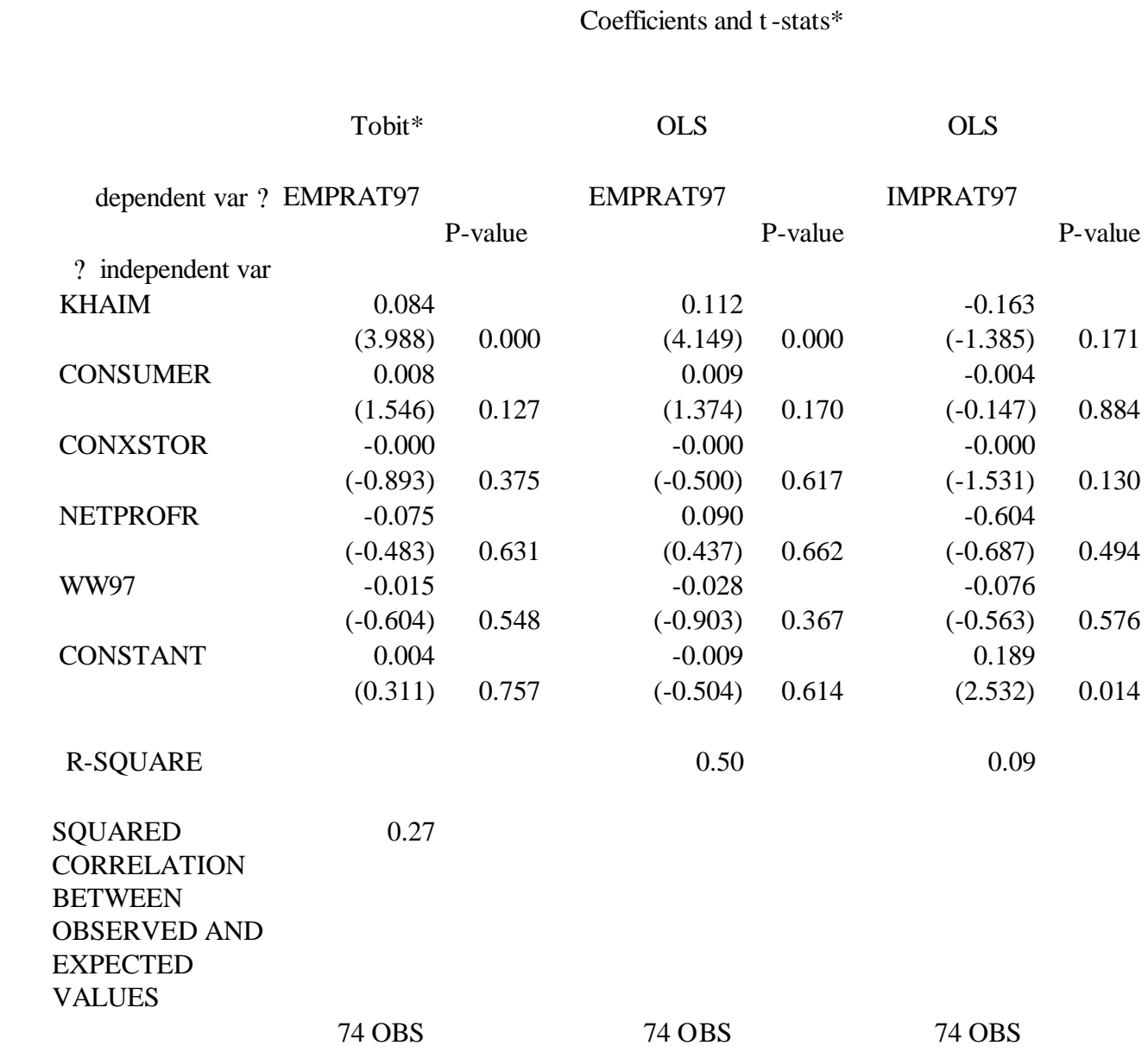

* The coefficients of the Tobit equation are those of the non -normalized variables. 
Table 4. Regression Estimates: Structural Equations

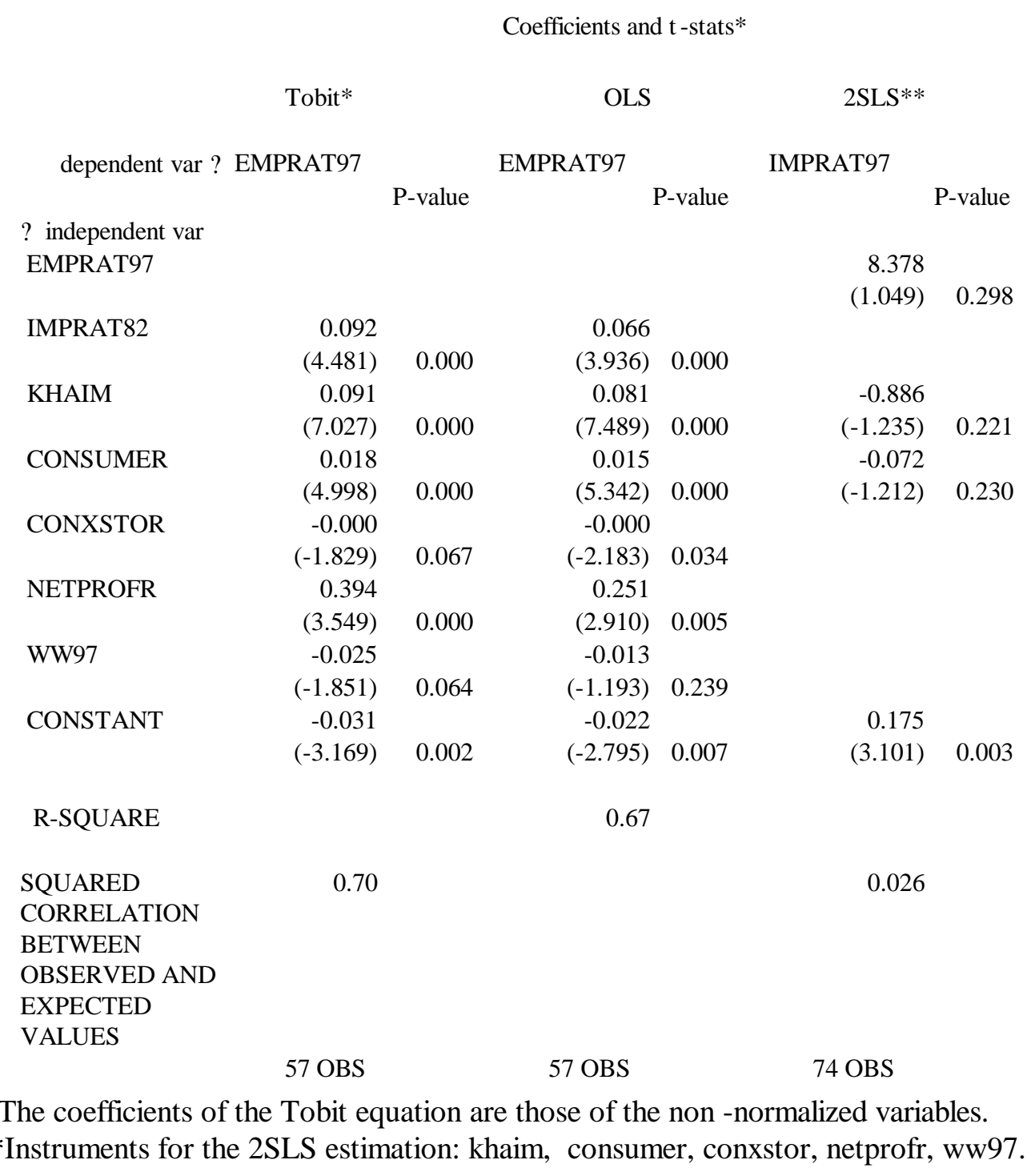

